Article

\title{
Comparative Analysis of Infrared Thermography and CFD Modelling for Assessing the Thermal Performance of Buildings
}

\author{
Carlos Morón ${ }^{1, *(1)}$, Pablo Saiz ${ }^{2}$ (1) , Daniel Ferrández ${ }^{1}$ and Rubén Felices ${ }^{1}$ (1) \\ 1 Departamento de Tecnología de la Edificación, Universidad Politécnica de Madrid, 28040 Madrid, Spain; \\ daniel.ferrandez.vega@alumnos.upm.es (D.F.); r.felices@alumnos.upm.es (R.F.) \\ 2 Departamento de Economía Financiera, Contabilidad e Idioma Moderno, Universidad Rey Juan Carlos, \\ 28040 Madrid, Spain; pablosaizm@gmail.com \\ * Correspondence: carlos.moron@upm.es; Tel.: +34-91-336-7583; Fax: +34-91-336-7637
}

Received: 16 February 2018; Accepted: 12 March 2018; Published: 13 March 2018

\begin{abstract}
Energy consumption in the building sector has increased significantly in the developed countries over the last decades. For this reason, the new European standards have become stricter in terms of energy saving. This paper establishes a comparison between using infrared thermography for technical building inspection and modelling with Computational Flow Dynamics (CFD) tools for the study of thermal performance of the building. The results show that the use of this type of tools gives a reliable response with the difference in thermal changes lower than $0.5^{\circ} \mathrm{C}$ with respect to the data taken in situ. Moreover, these simulators of flow dynamics allow to evaluate the efficiency of proposed measures for energy savings and to obtain a reliable approximation to thermal comfort applying the improvement, deepening in the surface analysis of infrared thermography before performing rehabilitation project. In this research, Predicted Mean Vote Index (PMV) comfort index of 0.7 for a living room and 0.6 for a bedroom were obtained, that corresponds to $C$ class that includes values in the range of $-0.7<$ PMV $<0.7$ according to the standard UNE-EN 7730.
\end{abstract}

Keywords: Computational Flow Dynamics (CFD analysis); infrared thermography; energy rating; energy rehabilitation; thermal comfort

\section{Introduction}

Even though currently international standards regulate energy demand of new buildings, both at the European and international levels there is a large number of buildings constructed before these legislations came into force. The progressive exhaustion of traditional energy sources and the tendency to create net-zero energy buildings, or buildings that demand the same as they are capable to produce, are fostering diverse activities to improve energy efficiency of buildings [1,2]. It is therefore required to use an appropriate analysis of thermal performance of buildings in order to ensure high environmental standards and to reduce its energy consumption [3].

The European Directive 2010/32 [4] referring to energy efficiency of buildings aims at fostering the use of renewable energy systems and in its Annex 1 defines the basic principles to be taken into consideration obtaining calculation methodology of energy demand. This Directive, since its first version was released in 2002, considered the application of the ergonomics principles stating the need to achieve a good indoor environmental quality (IEQ), as a result of thermal, visual, acoustic comfort and indoor air quality in full compliance with energy saving requirements (see also UNE EN 15251 Standard [5]). This Directive transposes Spanish legislation through the Technical Building Code (CTE) and HE Basic Document: Saving energy [6] and the Regulation of Thermal Installations in Buildings (RITE) [7], which establishes energy efficiency requirements for existing and new buildings. Moreover, 
the Royal Decree 235/2013 [8] regulates basic methodological procedure for energy certification of buildings. The rating is expressed by letters, starting from the letter $\mathrm{A}$, for the best performing buildings, to the letter $\mathrm{G}$, for the poor performing buildings. One of the reference programs for energy certification of existing residential buildings in Spain is the CE3X v.2.3 [9].

To improve energy performance of a building and to reduce $\mathrm{CO}_{2}$ emissions, it is important to know which factors affect its energy demand. Several researchers agree that the renovation of the thermal envelope of a building helps to improve its energy consumption. Thus, Capeluto and Ochoa carried out modelling of a facade concluding that this construction element consumes between $20 \%$ and $30 \%$ of energy demanded by a building [10]. That is why other authors used the system of double facade to improve energy efficiency [11], carrying out modellings in project phase in order to obtain the expected result compared to real data obtained with prototypes built to scale. In this way, it is possible to validate studied energy solution for its application in other climatic zones [12].

The knowledge of current state of conservation of a building is crucial for the proper intervention, however, it is not always easy to carry out this analysis because of a lack of available prior information and ignorance of the materials and techniques used in the construction [13]. In this context, infrared thermography can be an effective and significant tool for the identification of the construction systems used in existing buildings during the stages of study before rehabilitation. Furthermore, the use of this technology allows characterization of materials used in the thermal envelope [14,15], helps find hidden construction defects $[16,17]$, and can obtain buildings' interior temperatures using alternative and cheaper ways compared to building monitoring $[18,19]$.

Thermography was used by numerous researchers for construction elements analysis as a basis for the validation of results obtained through modelling programs. The analysis of construction elements such as doors [20], windows [21,22], vegetable roofs using software for the transient modelling such as EnergyPlus shows high agreement between the experimental data collection and results from simulations [23-26]. For this reason, experimental data collection using thermography serves as a basis for energy modelling of buildings through computer tools. Computational flow dynamics (CFD) analysis and finite-element calculation programs give reliable and very precise results [27,28]. Introducing previously physical parameters that allow building modelling, the program calculates internally heat transfer, giving easily interpretable results and becoming in such a way a tool of recognized prestige used in building projects $[29,30]$ and in the characterization of thermal performance of already built constructive elements [31].

Nowadays, there are a great variety of free or commercial programs for energy analysis of the building. In these software the specification of several physical parameters is necessary for modelling heat transfer phenomena within the building envelope by means of finite elements techniques. Obtained results are easy to interpret and allow to know the current state of the construction, and to implement improvement measures and visualize the effect they cause in the building. Table 1 includes some of the free software that are the most used in building and energy sector.

Table 1. Free software used in building projects.

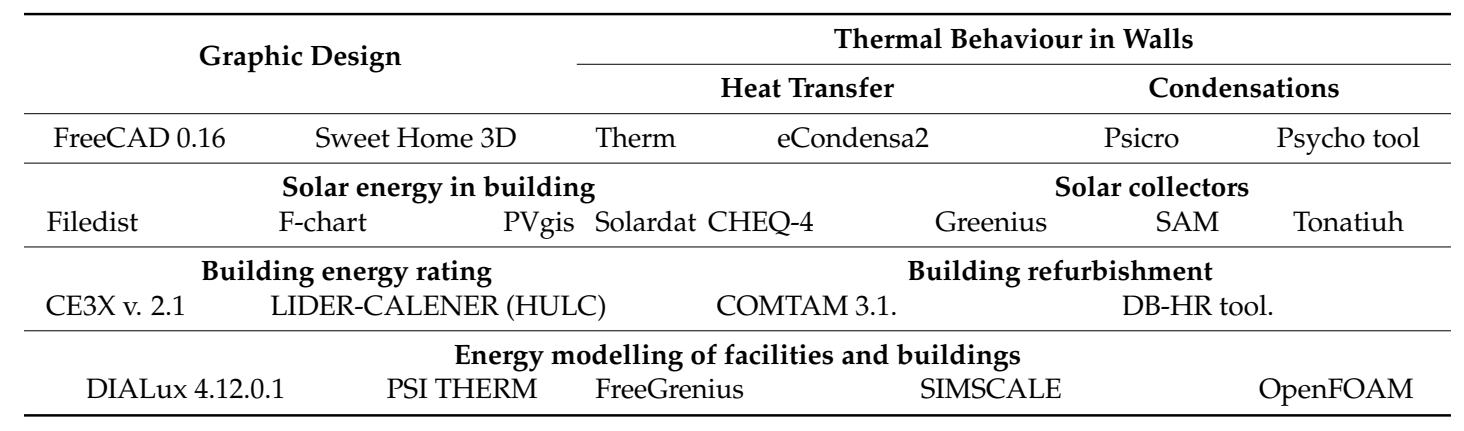


The software packages shown in Table 1 rival in terms of precision the simulation by finite elements of commercial products like Autodesk ${ }^{\odot}$ or ANSYS Fluent ${ }^{\odot}$ and some 3D design programs such as SOLIDWORKS ${ }^{\odot}$ or Rhinoceros ${ }^{\odot}$. The main advantage of free software is a possibility to modify the software source code, resulting in a cheaper solution for educational purposes. Nevertheless, commercial programs such as Star-CCM+8.05.006 used in this research provide after-sales support and a calculation capacity that makes them more competitive in industrial applications.

Several researchers have combined infrared thermography with simulation modelling to evaluate the thermal conditions of a building. Taylor et al. used thermography with heat transfer models to verify if the thermal conditions of a new building corresponded to the conditions planned at the design stage. The conclusion was that the combination of two techniques allows evaluation of thermal performance of facades during and after construction [32].

Asdrubali et al. studied the use of thermography combined with numerical modelling to quantify the impact of thermal bridges [33], proposing a quantitative methodology able to analyze thermal bridges by simple thermographic studies and its posterior analytic processing, obtaining relevant information that can help to understand the structure of thermal bridges and stratigraphy of façade in design phase. In the same line, Wróbel and Kisilewicz used numerical simulation to calculate surface temperatures at openings and junctions, comparing with thermal images for quantifying the impact of thermal bridges and the risk of surface condensation [34]. For this, the list of necessary data such as surface temperatures, climatic conditions, thermal fluctuations ... etc., is included in order to obtain reliable results while setting parameters for boundary conditions in programs of multidimensional heat flow simulation. Fox et al. also compared results obtained using thermography with numerical simulation to study the transient behaviour of materials [35]. This research stresses inherent problematic of interpretation of thermic images of real buildings, showing the importance of technical work in order to understand better the results and thermal performance of materials used in building.

A lot of the studies have compared thermography with a 2D numerical model, limiting the depth of the study to the analysis of the current state of the building, focusing on construction defects and thermal bridges [36]. However, full knowledge of thermal performance in 3D allows the evaluation of the current state of a building and, at the same time, the quantification and optimization of building improvement that includes aspects from energy saving quantification to the analysis of thermal comfort of residents of the building.

Therefore, the main aim of this research is the validation of CFD analysis procedure in 3D to study the thermal performance of buildings, construction defects in internal positions of building envelope and the thermal comfort of residents. To this aim, the validation of results obtained in CFD analysis of data collected through infrared thermography of a building was carried out for its future use in rehabilitation proposal development.

\section{Methodology}

This part defines the studied building, indicating materials and building envelope in order to evaluate its thermal performance. Furthermore, this part of a research fixes experimented conditions under which CFD modelling was carried out and that are related to the thermography measurments taken on the facade.

\subsection{Case Study}

The house analysed in this research is situated in Hoyo de Manzanares (Madrid, Spain). It is a village in the mountains of Madrid $\left(40^{\circ} 37^{\prime} 18^{\prime \prime} \mathrm{N} 3^{\circ} 54^{\prime} 33^{\prime \prime} \mathrm{O}\right)$, which has a predominant continental climate. Figure 1 shows interior layout plan of the house with different types of external walls and the analysed facade. The building was constructed in 1986 following the requirements of the standard NBE-79 [37], which is now repealed, without having received any interventions that improve its state during 30 years. The building is situated in the mountains of the Sierra of Madrid with latitude 
$40.39^{\circ} \mathrm{N}$ and longitude $3.47^{\circ} \mathrm{O}$. The most important difference between current CTE DB-HE and already disused NBE-79 is that nowadays the levels of solar radiation are considered when different climatic zones are defined, taking into consideration location of the building and its internal charge while defining envelope thermal characteristics. When the studied building was constructed, only the loss through transmission via parameters was considered and thermal insulation recommendations were not mandatory for external walls.

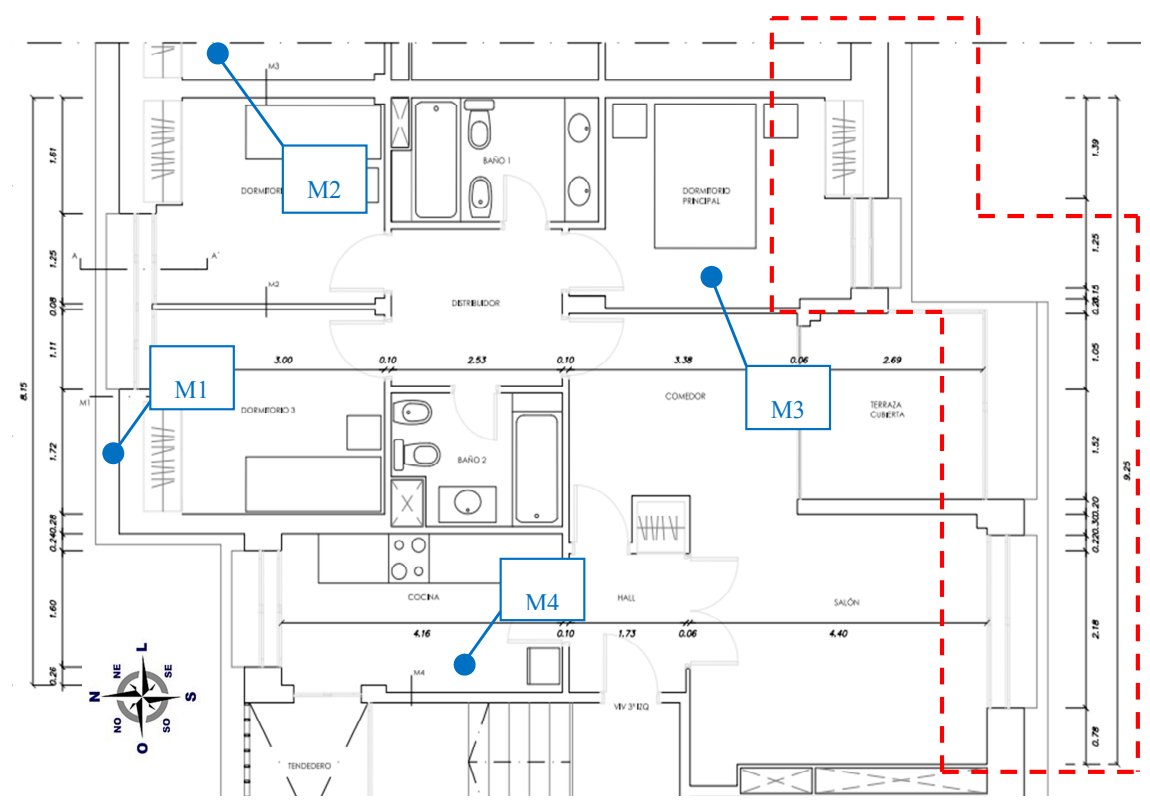

Figure 1. Layout plan and location of different walls.

\subsection{Materials and Initial Energy Rating}

Physical properties of building materials was obtained based on data collected from the construction project. These parameters were used to calculate thermal transmittance of different facade walls, used in the calculation of energy rating and modelling of the building. Project data is shown in Tables 2 and 3.

Once the composition of the walls was studied with the data collected from the actual state of the building, energy rating of the building was carried out using the CE3X v.2.3 [9] tool for residential buildings. To determine the energy performance of the building it was necessary to include the data of materials and transmittance through walls, the location of the building, a pattern of shadows of the facade and facilities of the building. The values of building elevation can be seen in Figure 2a, and the energy label obtained in the research is shown in Figure $2 b$, being this one the most common qualification for buildings based on the reference standard NBE-79.

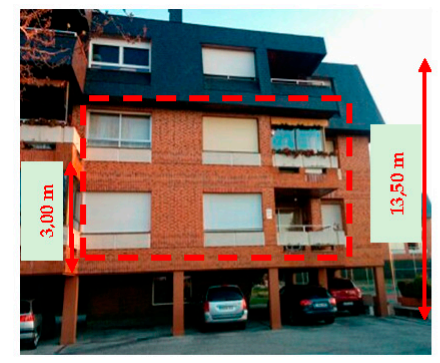

(a)

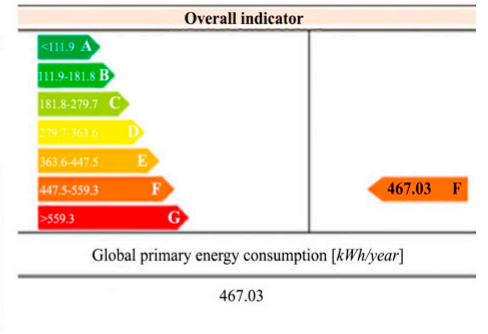

(b)

Figure 2. Analysed building. (a) Studied area; (b) Actual energy demand of each house. 
Table 2. Building materials properties.

\begin{tabular}{|c|c|c|c|c|c|c|}
\hline Material & $\rho\left(\mathrm{kg} / \mathrm{m}^{3}\right)$ & $\lambda(\mathrm{W} / \mathrm{mK})$ & c $(\mathrm{J} / \mathrm{kg} \cdot \mathrm{K})$ & Emissivity $(\varepsilon)$ & Reflectivity $(\rho) \mathrm{G}$ & Transmissivity $(\tau)$ \\
\hline $1 / 2$ Foot face brick & 780 & 0.35 & 1000 & 0.92 & 0.08 & 0.00 \\
\hline Cement mortar render & 2000 & 1.50 & 960 & 0.92 & 0.08 & 0.00 \\
\hline Unventilated air chamber & 1.20 & 0.024 & 1006 & 0.92 & 0.08 & 0.00 \\
\hline XPS Thermal insulation & 50 & 0.035 & 150 & 0.92 & 0.08 & 0.00 \\
\hline Hollow brick partition & 770 & 0.32 & 1000 & 0.92 & 0.08 & 0.00 \\
\hline Glass & 2500 & 3.00 & 840 & 0.70 & 0.20 & 0.10 \\
\hline Gypsum plastering & 750 & 0.30 & 1000 & 0.92 & 0.08 & 0.00 \\
\hline One-way slab & 1140 & 0.85 & 1000 & 0.92 & 0.08 & 0.00 \\
\hline
\end{tabular}

Table 3. Thermal transmittance through walls.

\begin{tabular}{ccccccc}
\hline & \multicolumn{3}{c}{ Vertical Walls } & & \multicolumn{2}{c}{ Horizontal Walls } \\
\hline Wall type & M1 & M2 & M3 & M4 & Wall type & Slab \\
$\mathrm{U}_{\mathrm{T}}\left(\mathrm{W} / \mathrm{m}^{2} \cdot \mathrm{K}\right)$ & 0.41 & 0.40 & 0.56 & 0.59 & $\mathrm{U}_{\mathrm{T}}\left(\mathrm{W} / \mathrm{m}^{2} \cdot \mathrm{K}\right)$ & 0.85 \\
\hline
\end{tabular}

\subsection{Thermography}

Thermography shows thermal radiation at determined wavelengths of analysed physical elements. This result is transformed into a numerical value that corresponds to its temperature by applying Stefan-Boltzmann's Law, shown in Equation (1); as this equation is applied to a black body that emits all absorbed radiation, it does not work for the majority of surrounding objects (grey objects). In this way, a modified expression such as Equation (2) can be used, that takes into account the emissivity $(\varepsilon)$ of a body in a way that the emissivity of a black body considered to be 1 and the emissivity of grey bodies considered to have a value between 0 and 1 .

$$
\begin{gathered}
Q_{\text {rad }}=\sigma \cdot A_{s} \cdot \theta_{s}^{4}(\mathrm{~W}) \\
Q_{\text {rad }}=\sigma \cdot \mathcal{E} \cdot A_{s} \cdot \theta_{s}^{4}(\mathrm{~W})
\end{gathered}
$$

Thermography shows images within a range of colours according to the pattern of each camera that corresponds to a number associated to each colour. For a correct interpretation of the results, the values have to be adjusted correctly, taking into consideration the recommendation of the standard UNE-EN ISO 7726 [38] for measuring microclimatic parameters it is possible to determine the indoor air temperature $\left(t_{a}\right)$ at which the image was taken.

This research was carried out using the first method, using a Ti90 camera (Fluke, Everett Washington, USA) with 4800 pixels resolution, thermal sensitivity $\leq 0.15{ }^{\circ} \mathrm{C}$ and measuring range from $-20{ }^{\circ} \mathrm{C}$ to $250{ }^{\circ} \mathrm{C}$. Moreover, it is needed to know the emissivity value of an object to take its thermography. For this reason, adhesive tape with $\varepsilon=0.95$ was used and the photo was taken from the minimum distance in a way that its area includes completely the camera's angle of vision. This previous data helps to interpret and assess correctly the obtained numerical data.

\subsection{Experimental Conditions}

Thermography images were taken on 17 March 2017 at 7:30 a.m. The studied facade has a west orientation, in a way that at dawn solar radiation does not impact the building directly, existing only a component of diffuse solar radiation. Environmental data was obtained in the micro climatic data logger located in the façade of the building. Heat transfer in the main direction of the facade and perpendicularly to it was considered. Taking as a calculation assumption the installed heating power system of the building, the power of the unit heaters was calculated according to the standard UNE-EN ISO 13790 which describes the calculation of the energy demand of heating [39]. The calculation method is expressed mathematically by Equations (3)-(6):

$$
Q_{\text {Total }}=Q_{\text {Trans }}+Q_{\text {Vent }}(\mathrm{W})
$$


The heat transfer variables can be obtained in the following way:

$$
\begin{aligned}
& Q_{\text {Trans }}=\left(\sum A_{i} \cdot U_{i}+l_{k} \cdot \psi_{k}\right) \cdot\left(\theta_{\text {int }, \text { set }}-\theta_{e}\right)(\mathrm{W}) \\
& Q_{\text {Vent }}=H \cdot\left(\theta_{\text {int }, \text { set }}-\theta_{e}\right)[\mathrm{W}]
\end{aligned}
$$

Moreover, the value of $H$ can be obtained using the following expression:

$$
H=\rho_{a} \cdot c_{a} \cdot Q_{\text {vent }}(W / K)
$$

The flows described in the CTE DB-HS3 were used for the minimum required ventilation flows in bedrooms and living rooms [40], without taking into consideration the infiltrations in the analysed model. As in the moment when thermography was taken the heating was switched on, Table 4 shows initial conditions for thermal modelling in terms of heat power in every room, as well as solar radiation parameters which correspond to the moment of measuring.

Table 4. Experimental conditions.

\begin{tabular}{ccc}
\hline Area & Initial Conditions & Other Parameters \\
\hline Bedroom 1 & Heater supplied energy: $646 \mathrm{~W}$ & Key temperature: 20 \\
\hline Living room & Heater supplied energy: $1053 \mathrm{~W}$ & Ambient temperature: -0.1 \\
\hline \multirow{2}{*}{ Living room of adjacent flat } & Heater supplied energy: $458 \mathrm{~W}$ & Direct radiation: $0 \mathrm{~W} / \mathrm{m}^{2}$ \\
& & Diffuse radiation: $10 \mathrm{~W} / \mathrm{m}^{2}$ \\
\hline
\end{tabular}

\subsection{Geometric Model}

To define the geometry used in the numeric simulation model, real dimensions of the building were taken as a reference. Moreover, to optimize calculation time in building simulation, thickness of objects are multiples of $5 \mathrm{~cm}$ and dimensions of the model were adjusted in CAD until a unified size was obtained for all the areas. Mesh was refined making it denser with smaller cells close to the facade of the building and in the windows, as well as in heaters and in the interfaces between different areas of the plan. Moreover, layers of air of $2 \mathrm{~cm}$ thickness were included in interior and exterior areas of the facade, in order to simulate correctly heat transferred through the solid surface of the facade in contact with flows that involve it through convection.

Figure 3 shows the geometric definition of the model that corresponds to the first two floors of the real building. To choose the size of the cells of the mesh of each area, the error depending on different mesh sizes was calculated. For this, investigations validated by Roache [41] were taken as a reference for simulation in CFD programs. This paper proposes the value of Grid Convergence Index (GCI) to quantify the error corresponding to the mesh size which provides the objective value that quantifies uncertainty in the model based on error estimation produced after mesh refining. The equations to calculate GCI are expressed as follows:

$$
\begin{gathered}
G C I=\frac{F_{s}|E|}{\left(1-r^{p}\right)} \\
E=\frac{f_{c}-f_{f}}{f_{f}} \\
r=\frac{h_{c}}{h_{f}}
\end{gathered}
$$

Thus, it deals with finding asymptotic value at which different mesh sizes converge. The security factor $\left(F_{S}\right)$ reduces range error produced in approximation between refined solution $f_{c}$ and unknown 
exact solution $f_{f}$, which is fixed in the value $F_{s}=3$. The difference between the original size of cells $h_{c}$ and refined size $h_{f}$ is related through coefficient $r$, as it is shown in Equation (9). Recommended values for $r=p=2$.

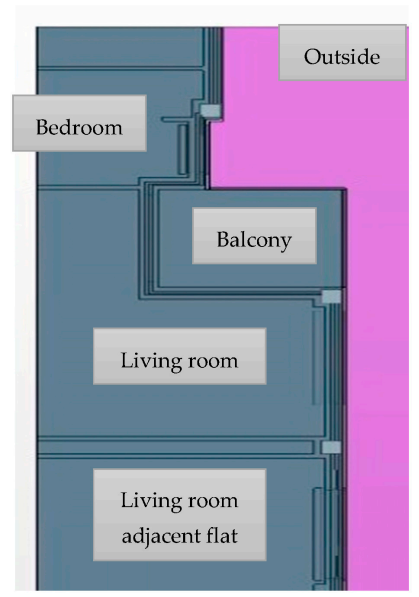

(a)

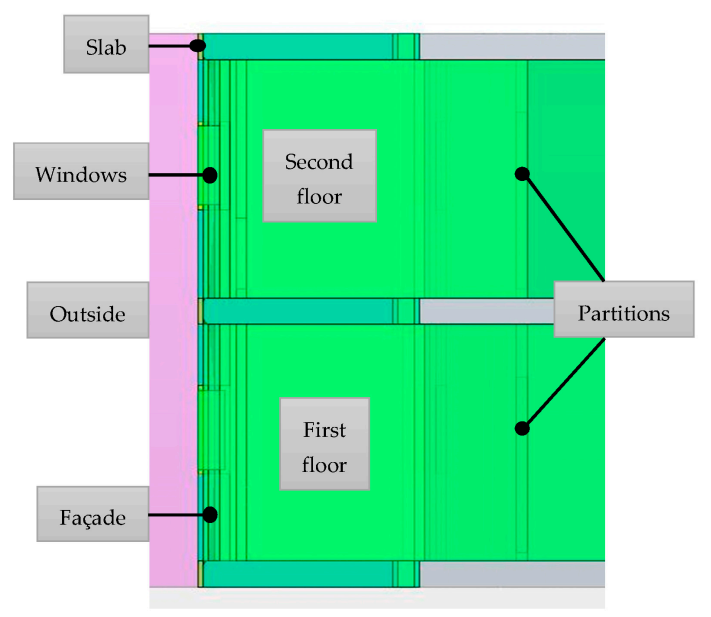

(b)

Figure 3. House model. (a) Floor section; (b) Construction section through facade.

The study of cells size was carried out on partial section of the facade due to the big size of the model as a whole. Thus, the obtained error between selected cells size and cells that are two or five times smaller is of $1.05 \%$ and $1.34 \%$, respectively, which can be considered as negligible assuming proposed mesh values for the modelling, reducing in this way the model calculation time.

Furthermore, it was decided to use polyhedral model in order to avoid errors produced in the surface common in the succession of layers of different material that form the enclosures, taking as a basis $5 \mathrm{~cm}$ mesh for all the areas. In case of areas of transfer between different objects, the size of the mesh was reduced with the use of two prismatic layers of $1 \mathrm{~cm}$ thickness, reducing in this way the error and refining the model in order to obtain higher continuity in stationary flow of heat between interior and exterior part of the building. Different types of the mesh used in the modelling are shown in Table 5, indicating the corresponding area.

Table 5. Mesh model.

\begin{tabular}{ccc}
\hline Body & Type of Cells & Mesh Size (cm) \\
\hline Ambient air & Polyhedric & 5 \\
Inner and unventilated chamber air & Polyhedric & 5 \\
Solid bodies & Polyhedric & 5 \\
Interfaces & Ortogonal (Prism layer) & Two layers of 1 cm each one \\
\hline
\end{tabular}

The simulated model is centered on the first and the second floor of the building, which are $14 \mathrm{~m}$ long and $7 \mathrm{~m}$ and $6 \mathrm{~m}$ high, respectively, as it can be observed in Figure 4. As a whole, the mesh used is composed by more than two million cells.

The comparison of the thermography taken in situ with the CFD modelling program was carried out as accurately as possible, imitating the process of building construction, taking into consideration the materials used in the original construction. This research used as a model of finite element simulation the Star-CCM+ 8.05.006 program [42]. This program was used in numerous studies related with building for the modelling of natural ventilation in the enclosures [43,44], and for observing the thermal performance of building envelopes under different constructive solutions $[45,46]$.

In order to analyse the thermal performance of the simulated building, boundary conditions were fixed allowing one to set differential equations that are resolved in modelling, indicating values of 
physical variables that allow comparing thermography with computational analysis. The simulated model is composed of 61 different zones according to the material, for this reason the values of corresponding physical parameters were taken into consideration for each one. Furthermore, some of the parameters were considered common for all of them, such as the gravity and the stratification of air flow, what was applied to movements of vertical convection in a condition of boundary between the facade and the air.

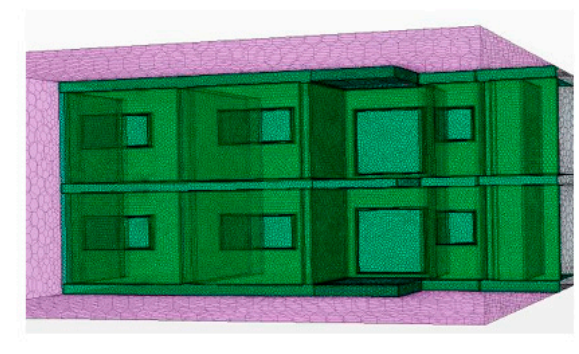

(a)

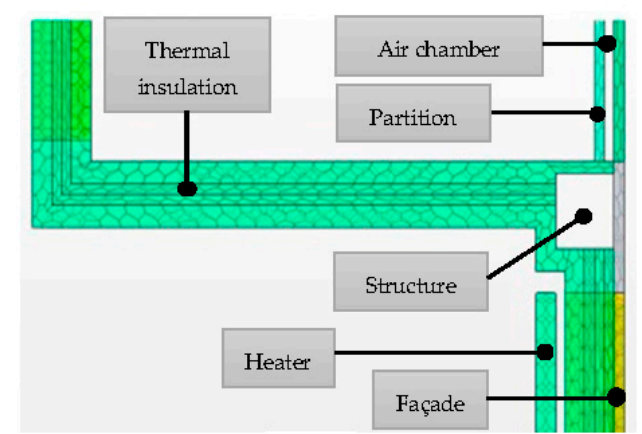

(b)

Figure 4. Model mesh. (a) Elevation of the building in perspective view; (b) Constructive detail of layers.

Heat flow transfer in stationary state between interior and exterior part of the building was calculated using Fourier's Law for the conduction between different solids being in contact (Equation (4)) and Newton's Law for the solid surfaces in contact with flows at different temperature (Equation (5)).

To simulate convective heat transfer, a model of approximate turbulence defined by the equations of Reynolds-Averaged Navier-Stokes (RANS) was used, obtaining instantaneous velocity and pressure decomposed to an average value and a fluctuating component in conditions of stationary balance. In particular, the effect of the turbulence has been defined using the Realizable k-epsilon model, validated in other studies to calculate natural convection flow [47,48].

Boundary conditions are the internal and external temperature. The air is modelled as an incompressible ideal gas. The effect of the gravitational forces is also included. The walls of the exterior volume air have been set to the external temperature. Moreover, the walls of the inner air volume have been set to the key temperature of the building. The heat transfer model analysed includes conduction, convection and radiation. In the specific case of heat transfer by radiation, a model surface to surface was used. This model is valid for explication of exchangeable radiation in area of diffuse grey surfaces. Thus, energy exchange between both surfaces depends partially on its size, distance of separation and orientation, being those the factor counted by so called view factor [49].

\section{Results}

Evaluation of the current state of the building according to CFD modelling is shown in Figure 5. General evaluation of thermal bridges through facade can be observed, especially in the intersections between the vertical parameters with horizontal structure of slabs.

Lack of insulation in these areas causes higher loss of heat per unit of surface that is reflected in the model in accordance with the predictions done for the real building. 

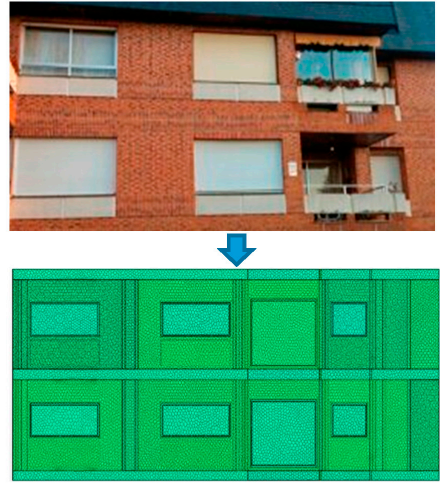

(a)

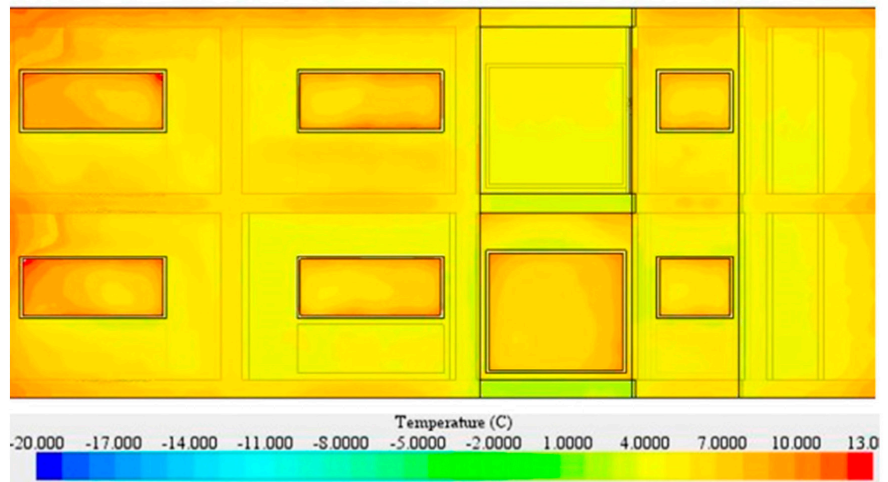

(b)

Figure 5. Modelling. (a) Studies area and mesh schematized; (b) Surface temperature of the facade $\left({ }^{\circ} \mathrm{C}\right)$.

\subsection{Thermography Analysis}

Thermographic images of the facade show thermal bridges in slab edges and pillars of the facade (Figure 6), as it can be seen in CFD modelling. A change of colour also can be observed under the windows, associated with an approximate temperature difference of $5{ }^{\circ} \mathrm{C}$ with respect to the rest of the facade where the average temperature is $3.5^{\circ} \mathrm{C}$. This variation corresponds with the location of heaters.

Deepening the analysis of the thermography, it can be observed how the exterior wall of the facade is made with different materials. On one side, first two floors are made with brick, a rough and opaque material with emissivity close to 1 , which is represented by a warm colour (Figure 6a). On the other hand, the last floor has a smooth slate finish that increases its reflectivity (Figure 6b); additionally its inclination is not vertical, what leads as a result in the thermography of the reflected sky temperature, explaining the difference between the demonstrated temperature and the brick wall temperature. Thus, brick temperature is closer to the reality, while slate temperature does not show reliable emissivity values and, consequently, it was discarded in the CFD model.

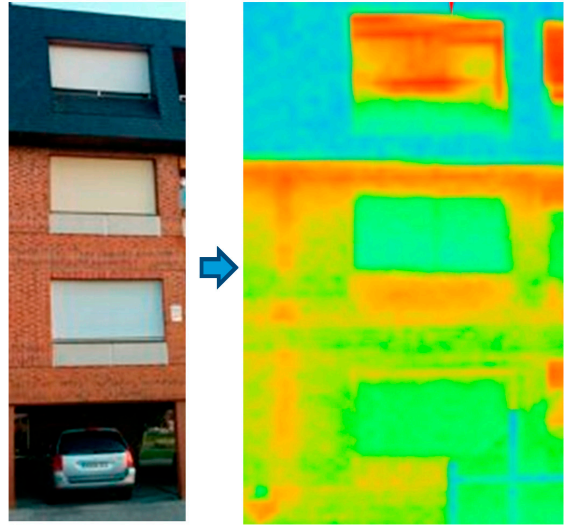

(a)

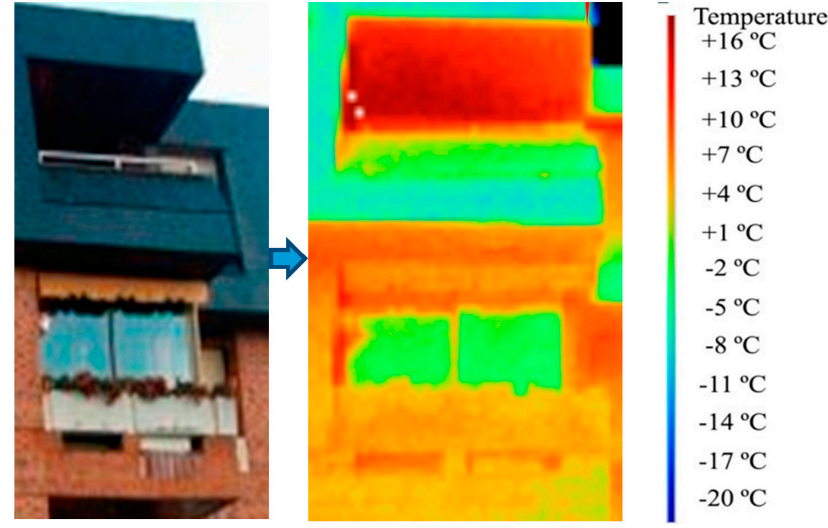

(b)

Figure 6. Building thermography $\left({ }^{\circ} \mathrm{C}\right)$. (a) Central zone; (b) End zone.

\subsection{Validation of the CFD Model}

The CFD model, that analyses different physical values in stationary state, was constructed using the characteristics established in the previous subsections. The validation was carried out through observation of phenomena highlighted in the thermography. Starting from the facade (Figure 7), as it 
can be observed that the CFD images become much more homogeneous without low temperature values, if we exclude the upper floor from the study.

Moreover, thermal bridges caused by lack of insulation around the structure are shown in the CFD image with a similar value to the one obtained by the thermography camera. The variation of the temperature values in the areas of the heaters and the convection air flow due to different density are also shown, reaching similar temperature values using both methods. For its validation through external part of the facade, three points were analysed using thermography and the CFD model. In these points, the difference between average temperatures varies between $0.6^{\circ} \mathrm{C}$ and $0.8^{\circ} \mathrm{C}$, being this difference lower than the precision of the thermographic camera making the error negligible.

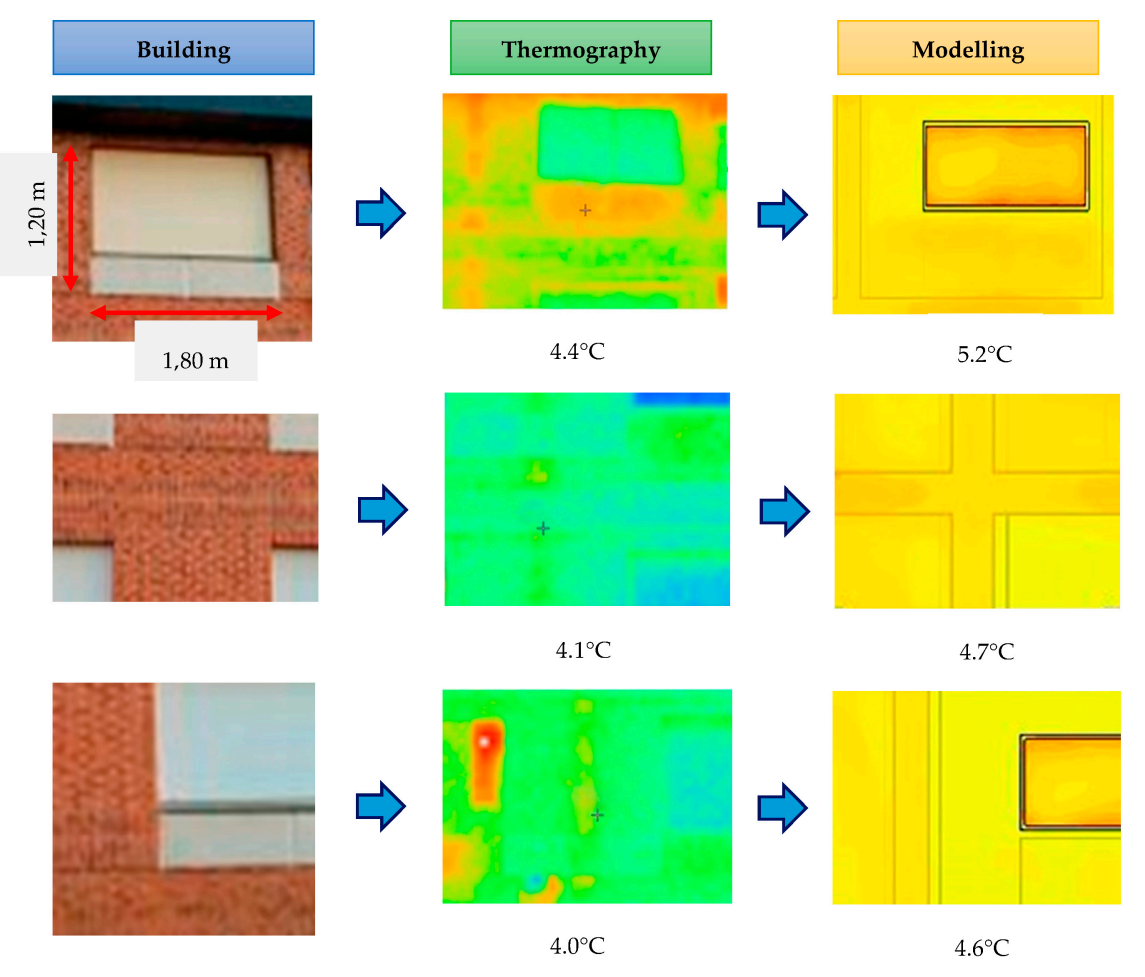

Figure 7. Surface temperature in different points of the facade. Comparison of Thermography and CFD modelling with Star-CCM+ 8.05.006.

\section{Discussion}

Once the numerical model of the building in 3D is obtained, it is possible to carry out a deeper analysis of its performance and to evaluate possible improvement suggestions. Beyond the results shown in Figures 5 and 7, where the lack of thermal insulation in vertical and horizontal walls can be seen emphasizing in this way thermal bridges, lack of double glazing and temperature gradients produced by natural convection inside the building, the given initial conditions should lead to a habitability result inside the building, which is analysed in Figure 8. The temperature obtained in the interior areas corresponds to similar values of the key temperature established inside the building $\left(\approx 20^{\circ} \mathrm{C}\right)$. The hottest areas correspond to the vertical projection of the heaters, as happens in reality. The ambient temperature is the same as the reference taken from the micro-climatic data logger $\left(0.1^{\circ} \mathrm{C}\right)$.

On the other hand, Figure 9 shows in detail the horizontal section of the second floor, being reached values in the interior areas $1.5^{\circ} \mathrm{C}$ higher than that of the lower floor. Air confined in the balcony is about $10^{\circ} \mathrm{C}$, absorbing the influence of the outside ambient temperature and reducing the energy consumption of the house. 


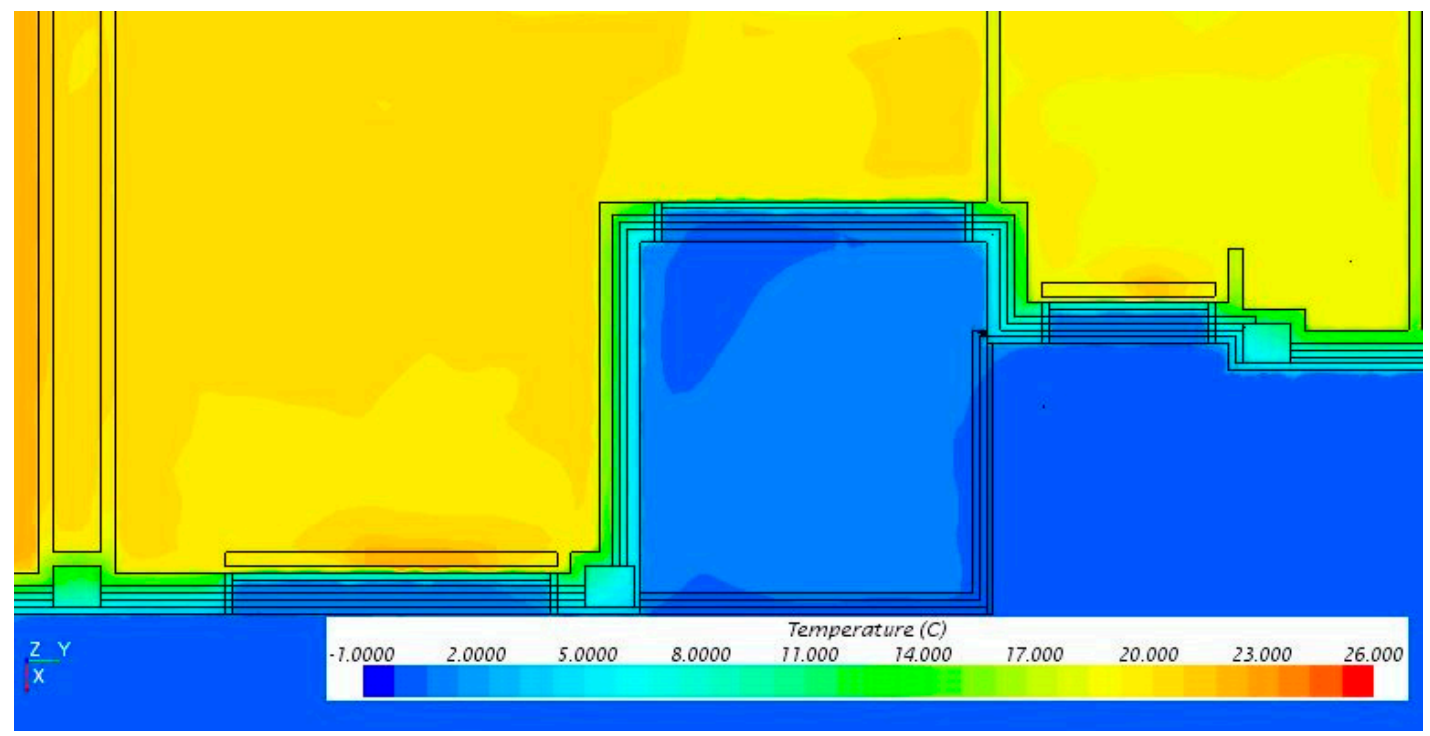

Figure 8. Temperatures shown in horizontal section of $1.7 \mathrm{~m}$ height on floor 1.

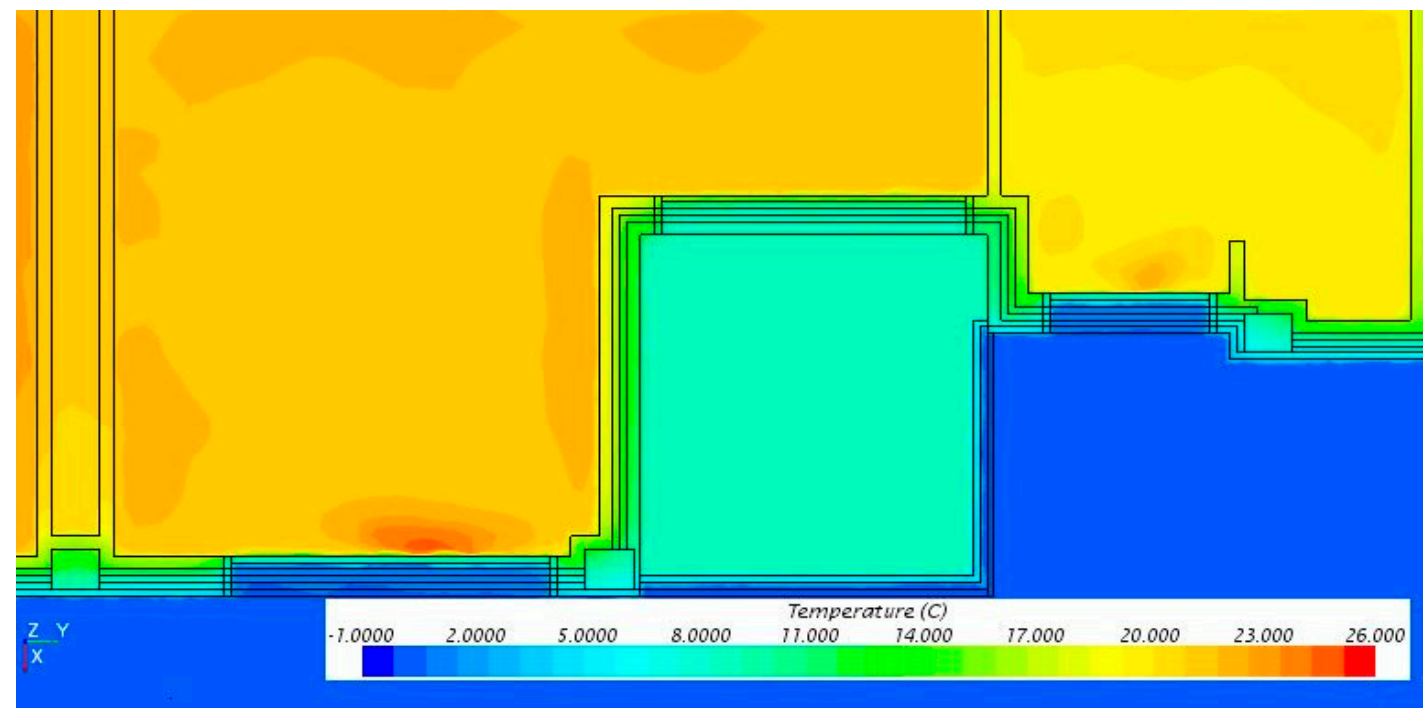

Figure 9. Horizontal section detail, showing influence of the balcony on floor 2, at the height of $1.7 \mathrm{~m}$.

Analysing other plans of the building, different from the facade, Figure 9 shows the vertical section of the building where it can be seen how the thermal bridge extends through the entire structural element because of lack of insulation in its outer slab front. The upper temperature range was limited to $25^{\circ} \mathrm{C}$, that is why the areas that surpass this value are white. The temperatures of the heaters in the model reach $50{ }^{\circ} \mathrm{C}$, coinciding with the usual temperature of the heating supply boiler temperature in the building, according to the current standard RITE-2013. Because of the lack of insulation, all the slabs act as thermal bridges, lower temperatures being observed in their exterior faces, while interior air becomes stratified responding to the gravitational behaviour according to which hotter flows ascend (Figure 10). 


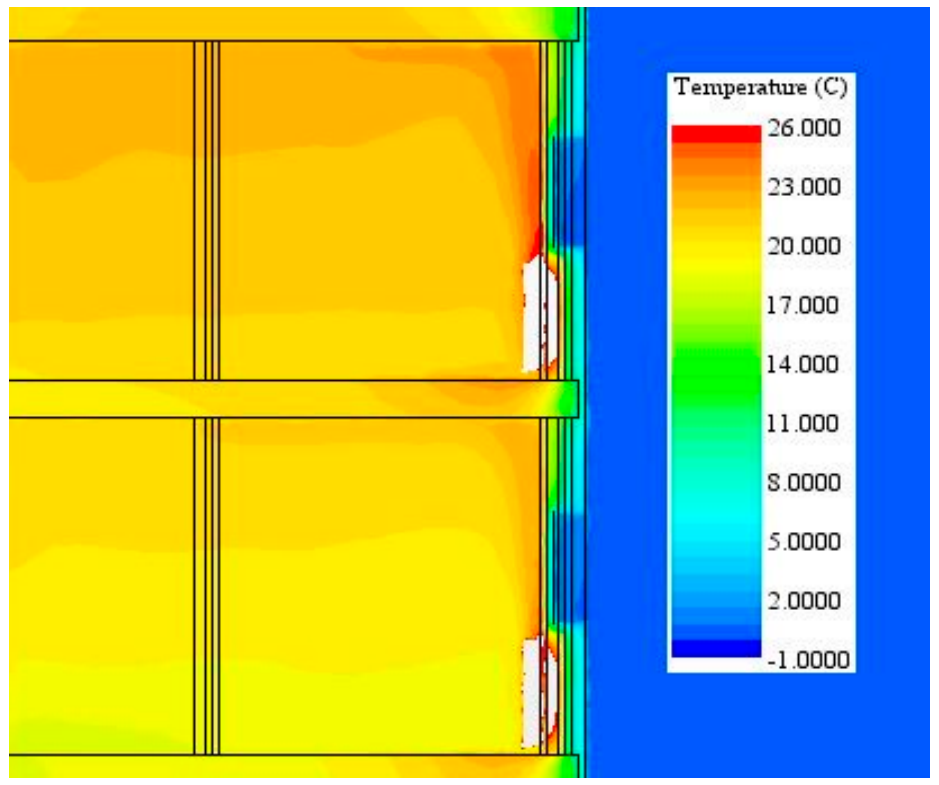

Figure 10. Building vertical section detail.

\section{Global and Local Comfort Assessment}

This kind of CFD programs also allows analysis of the thermal comfort of the residents. The standard UNE-EN ISO 7730 [50], relates thermal sensation with thermal balance, which depends on the physical activity, clothing of a subject, and other environmental parameters (air temperature, meant radiant temperature, air velocity and relative humidity). Thermal sensation can be estimated through Predicted Mean Vote (PMV) calculation and Predicted percentage of dissatisfied (PPD) index, which is defined from the PMV [50]. The PMV is expressed mathematically as described in the (10) and develops as follows in the Equations (11)-(13). The calculation of PMV index has been integrated in the Star-CCM+ simulations taking special care of all input variables required in Equations (10)-(13) as recently stressed by d'Ambrosio Alfano et al. [51,52]. In this way, all errors which affect also robust commercial tools have been minimized:

$$
\begin{aligned}
& P M V \\
& =[0.303 \cdot \exp (-0.036 \cdot M)+0.028] \\
& \cdot\left\{\begin{array}{c}
(M-W)-3.05 \cdot 10^{-3} \cdot\left[5733-6.99 \cdot(M-W)-p_{a}\right]-0.42 \cdot[(M-W)-58.15] \\
-1.7 \cdot 10^{-5} \cdot M \cdot\left(5867-p_{a}\right)-0.0014 \cdot M \cdot\left(34-t_{a}\right) \\
-3.96 \cdot 10^{-8} \cdot f_{c l} \cdot\left[\left(t_{c l}+273\right)^{4}-\left(\overline{t_{r}}+273\right)^{4}\right]-f_{c l} \cdot h_{c} \cdot\left(t_{c l}-t_{a}\right)
\end{array}\right\} \\
& \theta_{c l}=35.7-0.028 \cdot(M-W)-I_{c l} \cdot\left\{\begin{array}{c}
3.96 \cdot 10^{-8} \cdot f_{c l} \cdot\left[\left(t_{c l}+273\right)^{4}-\left(\overline{t_{r}}+273\right)^{4}\right] \\
+f_{c l} \cdot h_{c} \cdot\left(t_{c l}-t_{a}\right)
\end{array}\right\} \\
& h_{c}=\left\{\begin{array}{c}
2.38 \cdot\left|t_{c l}-t_{a}\right|^{0.25} \text { for } 2.38 \cdot\left|t_{c l}-t_{a}\right|^{0.25}>12.1 \sqrt{v_{a r}} \\
12.1 \sqrt{v_{a r}} \text { for } 2.38 \cdot\left|t_{c l}-t_{a}\right|^{0.25}<12.1 \sqrt{v_{a r}}
\end{array}\right\} \\
& f_{c l}=\left\{\begin{array}{c}
1.00+1.290 I_{c l} \text { for } I_{c l} \leq 0.078 \mathrm{~m}^{2} \cdot \mathrm{K} / \mathrm{W} \\
1.05+0.645 I_{c l} \text { for } I_{c l} \geq 0.078 \mathrm{~m}^{2} \cdot \mathrm{K} / \mathrm{W}
\end{array}\right\}
\end{aligned}
$$

Experimentally, the PMV value is obtained for a determined measurement point and the results are extrapolated to the studied area. However, the use of CFD simulation programs allows one to calculate PMV for each cell of the mesh used in the calculations. Metabolic rate was estimated according to the UNE-EN 7730 standard, taking into consideration that elderly persons often have 
lower activities compared to young persons. In this case, sedentary activity with average metabolic rate of $70 \mathrm{~W} / \mathrm{m}^{2}$ was considered for one person. Moreover, basic clothing insulation value of 1.0 clo was taken into account for calculations in winter season. Taking into account all closed openings in the moment of simulation, there is no considerable air flow inside the room, so a value of $0.05 \mathrm{~m} / \mathrm{s}$ for $v_{a}$ was considered according to the standard UNE EN ISO 7730. Mean radiant temperature $\overline{T_{r}}$ was calculated based on surface temperature of surrounding surfaces as indicated in the standard UNE-EN ISO 7726, assuming that temperature of opaque elements coincides with the air temperature due to high emissivity of building materials. For this, the Equation (14) established by the standard is used:

$$
{\overline{T_{r}}}^{4}=T_{1}^{4} \cdot F_{p-1}+T_{2}^{4} \cdot F_{p-2}+\ldots+T_{N}^{4} \cdot F_{p-N}
$$

where $\overline{T_{r}}$ is mean radiant temperature in $\mathrm{K}, T_{N}$ is $\mathrm{N}$ surface temperature, in $\mathrm{K}$ and $F_{p-N}$ is a factor of form between one person and $N$ surface.

The results obtained in the analysis of the thermal comfort are shown in Figure 11, where it can be observed that the values vary inside each area according to the previously described variables. The values of 0.7 in the living room and 0.6 in the bedroom are obtained applying one measure to each represented surface. These values correspond to a slightly hot thermal sensation in the interior of the house, listed in the class $C$ according to the standard UNE-EN 7730 that indicates dissatisfaction rates due to different considered factors global thermal discomfort.

However, asymmetry of radiant temperature can cause discomfort, for this reason this factor has been taken into consideration in the worst case considering the façade as a cold wall that according to the standard UNE EN ISO 7730 is indicated by:

$$
P D=\frac{100}{1+\exp \left(6.61-0.345 \cdot \Delta t_{p r}\right)}
$$

where $P D$ is the percentage of unsatisfied $(\%)$, and $\Delta t_{p r}$ is the asymmetry of radiant temperature $\left({ }^{\circ} \mathrm{C}\right)$.

In the given CFD model, the average temperature of each surface was obtained using mean value in each boundary. For the studied building, the living rooms of both houses present differences, as on the floor 1 the balcony is open to the exterior, when on the floor 2 there is a second line of window on the external edge of the balcony what makes it closed. As it can be seen in Table 6, the difference between temperatures of both areas provokes the minor percentage of unsatisfied inhabitants on the floor of closed balcony.

Table 6. PD temperatures and values obtained in living rooms of both studied floors.

\begin{tabular}{cccc}
\hline Living Rooms & $\begin{array}{c}\text { Average Temperature of } \\
\text { the Inner Side of the } \\
\text { Window }\left({ }^{\circ} \mathbf{C}\right)\end{array}$ & $\begin{array}{c}\text { Average Temperature of } \\
\text { the Opposite Wall }\left({ }^{\circ} \mathbf{C}\right)\end{array}$ & $\begin{array}{c}\text { Percentage of } \\
\text { Dissatisfied PD (\%) }\end{array}$ \\
\hline Floor 1 & 8.9 & 18.1 & 3.1 \\
Floor 2 & 14.8 & 20.0 & 0.8 \\
\hline
\end{tabular}

It is necessary to indicate the importance of the works of Povl Ole Fanger focused on the investigation of parameters that affect indoor air quality and can be used even nowadays as a reference in performing researches of this type [53]. In particular, in PMV parameters calculation, there is a great amount of applications both free and commercial. However, not all of them provide reliable results that can be used in building projects [54], that gives an additional value to this simulation with Star-CCM+ that allow treating this thermal comfort parameter with a high level of precision. Some authors such as Gan [55], already used more than two decades ago the calculation of comfort index to evaluate distribution of air inside an area. More recently, Gao et al. [56,57], used PMV calculation in the study of radiant cooling system and thermal comfort associated to its use; performing simulations for different temperature conditions in spite of the asymmetry presented in some cases, with an aim to optimize the 
design of the building. Other authors such as Huan et al. [58], calculated PMV index obtaining good results for the simulation of stratified ventilation in offices using highly asymmetric gains of heat.

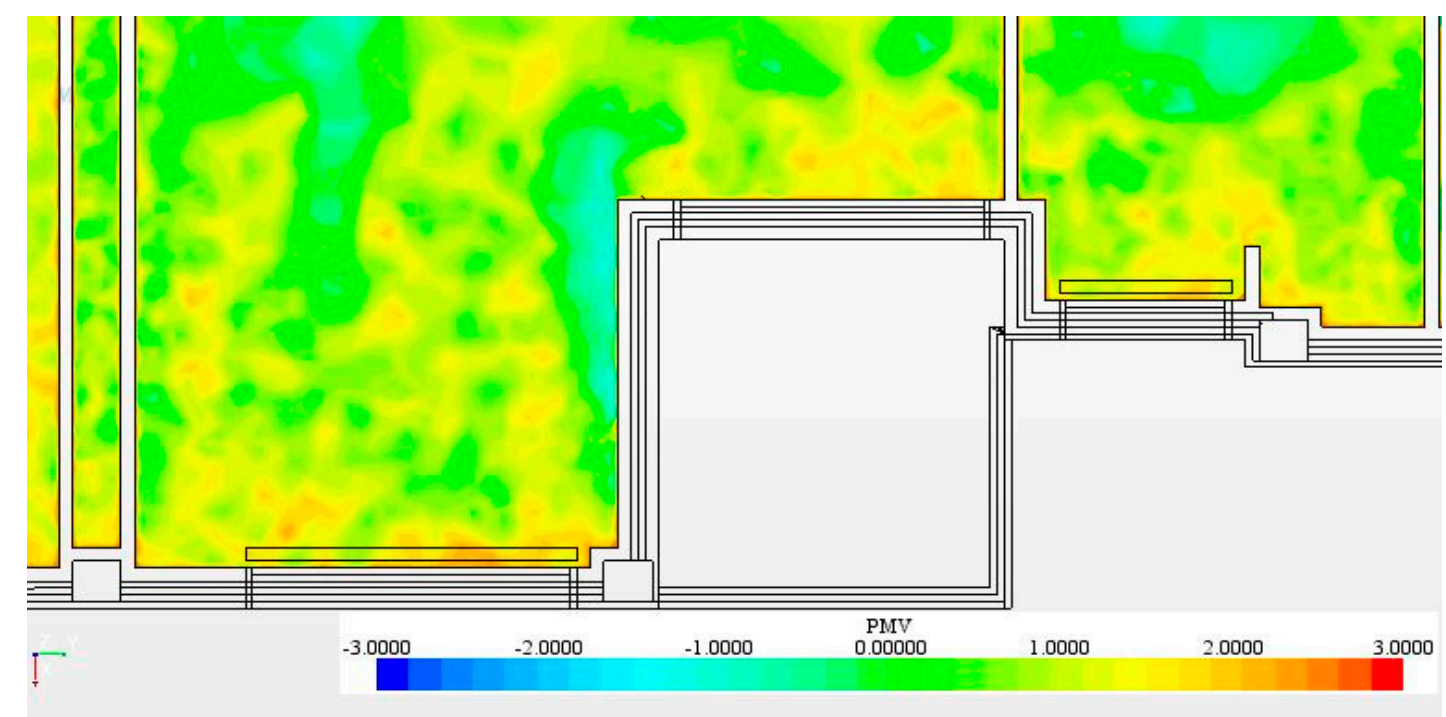

Figure 11. Prediction Mean Vote (PMV) on floor 1.

Thus, the use of CFD programs in the calculation of thermal comfort allows one to deepen and calculate thermal sensation in each point calculated by the mesh volume instead of considering it uniform throughout all the area, as it is done experimentally. Moreover, the use of this type of tool allows optimal evaluation of improvement suggestions without acting on analysed building. Analysed improvement suggestion as an example consists in filling the actual air chamber with thermal insulation with density of $30 \mathrm{~kg} / \mathrm{m}^{3}$ and thermal conductivity of $0.035 \mathrm{~W} /(\mathrm{m} \mathrm{K})$, with the aim to reduce the loss of energy through the facade reducing the thermal bridges of the building.

As this evaluation is stationary at a particular moment, the same calculation procedure was carried out for the heaters power followed in the Section 2.4, in other words, the Equations (3)-(6) and data of Table 3 were taken into consideration. Theoretical calculation of the heaters power turns out to be $11 \%$ lower-over the values shown in Table 2-than in the current state, what allows optimization of energy consumption.

The results obtained using the CFD model is shown in Table 7, where the temperatures of the rooms and the thermal sensation of the residents can be also observed. Comparing all these results, it can be observed that after improvements and maintaining the heaters power the temperature and thermal sensation increase. If on the contrary, both parameters (temperature and thermal sensation) maintained fixed, the reduction of $11 \%$ of energy used by heaters is obtained, what increases at the same rate saving of a user and energy efficiency.

Table 7. Results obtained through the CFD model.

\begin{tabular}{|c|c|c|c|c|c|c|}
\hline \multirow{4}{*}{$\begin{array}{l}\text { Subject } \\
\text { Building }\end{array}$} & \multicolumn{2}{|c|}{ Current State } & \multicolumn{2}{|c|}{$\begin{array}{l}\text { Improves Suggestion and } \\
11 \% \text { Less Power of Heaters }\end{array}$} & \multicolumn{2}{|c|}{$\begin{array}{l}\text { Improves Suggestion and } \\
\text { Heaters with Actual Power }\end{array}$} \\
\hline & Living Room & Bedroom & Living Room & Bedroom & Living Room & Bedroom \\
\hline & Mean Air & Mean Air & Mean Air & Mean Air & Mean Air & Mean Air \\
\hline & $\begin{array}{l}\text { Temperature } \\
\left({ }^{\circ} \mathrm{C}\right) / \mathrm{PMV}\end{array}$ & $\begin{array}{l}\text { Temperature } \\
\left({ }^{\circ} \mathrm{C}\right) / \mathrm{PMV}\end{array}$ & $\begin{array}{l}\text { Temperature } \\
\left({ }^{\circ} \mathrm{C}\right) / \mathrm{PMV}\end{array}$ & $\begin{array}{l}\text { Temperature } \\
\left({ }^{\circ} \mathrm{C}\right) / \mathrm{PMV}\end{array}$ & $\begin{array}{l}\text { Temperature } \\
\left({ }^{\circ} \mathrm{C}\right) / \mathrm{PMV}\end{array}$ & $\begin{array}{l}\text { Temperature } \\
\left({ }^{\circ} \mathrm{C}\right) / \mathrm{PMV}\end{array}$ \\
\hline Floor 2 & $21.7 / 1$ & $20.0 / 0.75$ & $21.6 / 1$ & $19.8 / 0.7$ & $22.7 / 1.16$ & $21.1 / 0.91$ \\
\hline Floor 1 & $20.2 / 0.75$ & $19.2 / 0.62$ & $20.1 / 0.77$ & $19.0 / 0.6$ & $21.2 / 0.92$ & $20.3 / 0.79$ \\
\hline
\end{tabular}




\section{Conclusions}

The thermography analysis of the building's facade allowed a comparable 3D numerical model using a CFD modelling tool, obtaining a similar thermal performance with both methodologies. In both techniques the influence of the lack of insulation on the heat loss through the facade can be observed. Moreover, CFD model allows to correct the temperatures that are in such elements of high reflectivity as glass and slate are incorrect in the thermography, being opaque material those that have to be considered to validate the comparison of two methodologies.

Global difference between measures with thermographic camera and those obtained by modelling for the same points varies between $0.6{ }^{\circ} \mathrm{C}$ and $0.9{ }^{\circ} \mathrm{C}$. Thus, the interior temperature in studied areas in the CFD model varies by $1{ }^{\circ} \mathrm{C}$ maximum with regard to the real average temperature in the building. That is why both levels of error are under the precision of measuring elements used for the in situ tests, being therefore comparable the results obtained by modelling with thermography images.

Moreover, CFD analysis allows, contrary to infrared thermography, assessing the influence of each material of facade and its envelope, providing in such a way more information. Therefore, it is possible to evaluate during rehabilitation the influence of different energy saving measures on the building. As an example, an improvement can be observed when the air chamber is replaced by the projected thermal insulation allowing a reduction of the energy demand of the building by $11 \%$.

Another advantage over visual inspection techniques and experimental measures, is that the use of modelling programs such as Star-CCM+ makes it possible to evaluate the thermal comfort of the building allowing one to perform quantitative analysis of thermal comfort in the studied area. In particular, a 0.6 value was obtained in the PMV index calculation, which classifies the house as C class according to the UNE EN ISO 7730 standard. This value adds a significant value to the research as European legislation indicates that energy efficiency of a building has to be guaranteed taking into consideration the thermal comfort of inhabitants, being necessary to complete rehabilitation works with a prediction in terms of indoor comfort before starting any installation.

Acknowledgments: The authors would like to show their gratitude for the collaboration to the Energy Efficiency and Thermal Solar Energy Departments of the Salesianos Carabanchel center of Madrid and to the Technical University School of Building Engineering of the Universidad Politécnica de Madrid.

Author Contributions: Pablo Saiz and Daniel Ferrández created and designed the experiments. Ruben Felices and Carlos Morón performed the experiments; Daniel Ferrández, Ruben Felices and Pablo Saiz analysed the data and wrote the article. Carlos Morón helped to analyse the documents.

Conflicts of Interest: The authors declare no conflict of interest.

\section{Nomenclature}

$\begin{array}{ll}\text { Symbol } & \text { Definition and Units } \\ A & \text { Area of the specimen }\left(\mathrm{m}^{2}\right) \\ A_{s} & \text { Surface area }\left(\mathrm{m}^{2}\right) \\ A_{i} & \text { Envelope surface area }\left(\mathrm{m}^{2}\right) \\ c & \text { Specific heat }(\mathrm{J} / \mathrm{kg} \cdot \mathrm{K}) \\ c_{a} & \text { Air calorific power }=1.200\left(\mathrm{~J} / \mathrm{m}^{3} \cdot \mathrm{K}\right) \\ E & \text { Difference in results from each grid } \\ f_{c} & \text { Variable value at a point with coarse grid }(\mathrm{K}) \\ f_{c l} & \text { Clothing surface area factor }(-) \\ f_{f} & \text { Variable value at a point with fine grid }(\mathrm{K}) \\ F_{s} & \text { Factor of safety } \\ G C I & \text { Grid Convergence Index } \\ H_{c} & \text { Convective heat transfer coefficient }(\mathrm{W} / \mathrm{K}) \\ h_{c} & \text { Representative grid size of coarse grid }(\mathrm{cm}) \\ h_{f} & \text { Representative grid size of fine grid }(\mathrm{cm}) \\ k & \text { Heat transfer coefficient }\left(\mathrm{W} / \mathrm{m}^{2} \cdot \mathrm{K}\right) \\ l_{k} & \text { Thermal bridge longitude }(\mathrm{m})\end{array}$




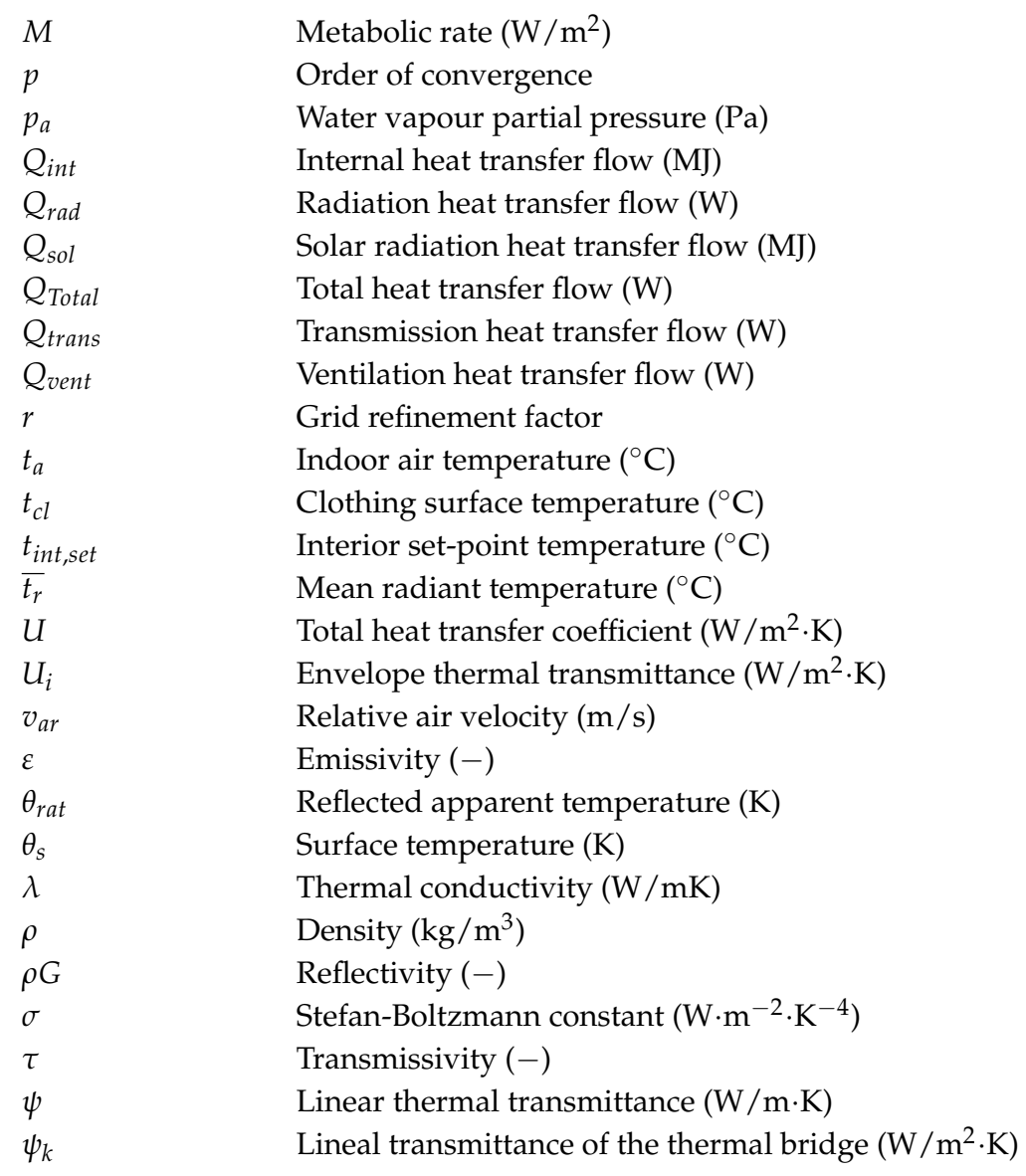

\section{References}

1. Deng, S.; Wang, R.Z.; Dai, Y.J. How to evaluate performance of net zero energy building-Review. Energy 2014, 71, 1-16. [CrossRef]

2. Faludi, J.; Lepech, M.D.; Loisos, G. Using life cycle assessment methods to guide architectural decision-making for sustainable prefabricated modular buildings. J. Green Build. 2012, 7, 151-170. [CrossRef]

3. García-Alvarado, R.; González, A.; Bustamante, W.; Bobadilla, A.; Muñoz, C. Critical features of energy simulation for single housing. Inf. Constr. 2014, 66, 1-13. [CrossRef]

4. Commission, E. Directive 2010/31/EU of the European Parliament and of the Council of 19 May 2010 on the energy performance of buildings (recast). Off. J. Eur. Union 2010, 13-35. [CrossRef]

5. UNE EN ISO 15251:2008. In Indoor Environmental Input Parameters for Design and Assessment of Energy Performance of Buildings Addressing Indoor Air Quality, Thermal Environment, Lighting and Acoustics; AENOR: Madrid, Spain, 2008; pp. 1-50.

6. Ministerio de Fomento. Orden FOM/1635/2013, de 10 de Septiembre, por la que se Actualiza el Documento Básico DB-HE «Ahorro de Energía», del Código Técnico de la Edificación, Aprobado por Real Decreto 314/2006, de 17 de Marzo. Available online: http:/ / noticias.juridicas.com/base_datos/Admin/ 512902-orden-fom-1635-2013-de-10-de-septiembre-por-la-que-se-actualiza-el-documento.html (accessed on 15 February 2018).

7. Reglamento de Instalaciones Térmicas de Edificios. Real Decreto 1027/2007, de 20 de julio, de la Presidencia del Gobierno. Available online: https:/ / www.sepin.es/administrador-de-finques /VerDoc.asp?referencia= SP\%2FLEG\%2F6054\&cod=0JP2MQ2AG0Hb07r0H00Fa2JJ1jR0Fk1S_0\%26G0Fa1\%2Fo1z10Ha1yA01\% 3D0Fa17P0X10G_1q\%261zl (accessed on 15 February 2018).

8. Spanish Government. Real Decreto 235/2013, de 5 de abril, por el que se aprueba el procedimiento básico para la certificación de la eficiencia energética de los edificios, 2010. BOE 2013, 89, 1-16.

9. Efinova, CE3X. 2016. Available online: http:/ / www.efinova.es/CE3X (accessed on 12 December 2007). 
10. Capeluto, I.G.; Ochoa, C.E. Simulation-based method to determine climatic energy strategies of an adaptable building retrofit facade system. Energy 2014, 76, 375-384. [CrossRef]

11. Fonseca I Casas, P.; Fonseca I Casas, A.; Garrido-Soriano, N.; Godoy, A.; Pujols, W.; García, J. Solution Validation for a Double Façade Prototype. Energies 2017, 10, 2013. [CrossRef]

12. Schuetze, T.; Willkomm, W.; Roo, M. Development of a Holistic Evaluation System for BIPV Façades. Energies 2017, 8, 6135. [CrossRef]

13. Bauer, E.; Pavón, E.; Barreira, E.; De Castro, E.K. Analysis of building facade defects using infrared thermography: Laboratory studies. J. Build. Eng. 2016, 6, 93-104. [CrossRef]

14. Grinzato, E.; Vavilov, V.; Kauppinen, T. Quantitative infrared thermography in buildings. Energy Build. 1998, 29, 1-9. [CrossRef]

15. Fokaides, P.A.; Kalogirou, S.A. Application of infrared thermography for the determination of the overall heat transfer coefficient (U-Value) in building envelopes. Appl. Energy 2011, 88, 4358-4365. [CrossRef]

16. Bagavathiappan, S.; Lahiri, B.B.; Saravanan, T.; Philip, J.; Jayakumar, T. Infrared thermography for condition monitoring-A review. Infrared Phys. Technol. 2013, 60, 35-55. [CrossRef]

17. Balaras, C.A.; Argiriou, A.A. Infrared thermography for building diagnostics. Energy Build. 2002, 34, 171-183. [CrossRef]

18. Porras-Amores, C.; Mazarrón, F.R.; Cañas, I. Using quantitative infrared thermography to determine indoor air temperature. Energy Build. 2013, 65, 292-298. [CrossRef]

19. Ascione, F.; De Masi, R.F.; de Rossi, F.; Ruggiero, S.; Vanoli, G.P. MATRIX, a multi activity test-room for evaluating the energy performances of "building/HVAC" systems in Mediterranean climate: Experimental set-up and CFD/BPS numerical modelling. Energy Build. 2016, 126, 424-446. [CrossRef]

20. Nussbaumer, T.; Bundi, R.; Tanner, C.; Muehlebach, H. Thermal analysis of a wooden door system with integrated vacuum insulation panels. Energy Build. 2005, 37, 1107-1113. [CrossRef]

21. Montazeri, H.; Blocken, B.; Derome, D.; Carmeliet, J.; Hensen, J.L.M. CFD analysis of forced convective heat transfer coefficients at windward building facades: Influence of building geometry. J. Wind Eng. Ind. Aerodyn. 2015, 146, 102-116. [CrossRef]

22. Baldinelli, G.; Bianchi, F. Windows thermal resistance: Infrared thermography aided comparative analysis among finite volumes simulations and experimental methods. Appl. Energy 2014, 136, 250-258. [CrossRef]

23. Nussbaumer, T.; Ghazi Wakili, K.; Tanner, C. Experimental and numerical investigation of the thermal performance of a protected vacuum-insulation system applied to a concrete wall. Appl. Energy 2006, 83, 841-855. [CrossRef]

24. Sailor, D.J. A green roof model for building energy simulation programs. Energy Build. 2008, 40, 1466-1478. [CrossRef]

25. U.S. Department of Energy (DOE). EnergyPlus 2016. Available online: https:/ / energyplus.net/ (accessed on 27 June 2016).

26. Padilla-Marcos, M.A.; Meiss, A.; Feijó, J. Proposal for a simplified CFD procedure for obtaining patterns of the age of air in outdoor spaces for the natural ventilation of buildings. Energies 2017, 10, 1252. [CrossRef]

27. Dall'O', G.; Sarto, L.; Sanna, N.; Martucci, A. Comparison between predicted and actual energy performance for summer cooling in high-performance residential buildings in the Lombardy region (Italy). Energy Build. 2012, 54, 234-242. [CrossRef]

28. Allegrini, J.; Dorer, V.; Carmeliet, J. Coupled CFD, radiation and building energy model for studying heat fluxes in an urban environment with generic building configurations. Sustain. Cities Soc. 2015, 19, 385-394. [CrossRef]

29. Kim, D.; Braun, J.E.; Cliff, E.M.; Borggaard, J.T. Development, validation and application of a coupled reduced-order CFD model for building control applications. Build. Environ. 2015, 93, 97-111. [CrossRef]

30. Ardkapan, S.R.; Nielsen, P.V.; Afshari, A. Studying passive ultrafine particle dispersion in a room with a heat source. Build. Environ. 2014, 71, 1-6. [CrossRef]

31. Montazeri, H.; Blocken, B.; Janssen, W.D.; van Hooff, T. CFD evaluation of new second-skin facade concept for wind comfort on building balconies: Case study for the Park Tower in Antwerp. Build. Environ. 2013, 68, 179-192. [CrossRef]

32. Taylor, T.; Counsell, J.; Gill, S. Combining thermography and computer simulation to identify and assess insulation defects in the construction of building façades. Energy Build. 2014, 76, 130-142. [CrossRef] 
33. Asdrubali, F.; Baldinelli, G.; Bianchi, F. A quantitative methodology to evaluate thermal bridges in buildings. Appl. Energy 2012, 97, 365-373. [CrossRef]

34. Wróbel, A.; Kisilewicz, T. Detection of thermal bridges-Aims, possibilities and conditions. In Proceedings of the Qirt, Cracow, Poland, 2-5 July 2008; pp. 2-7.

35. Fox, M.; Coley, D.; Goodhew, S.; Wilde, P.D. Comparing Transient Simulation with Thermography Time Series. In Proceedings of the First Building Simulation and Optimization Conference, Loughborough, UK, 10-12 September 2012; pp. 356-363.

36. Freund, S.; Kabelac, S. Investigation of local heat transfer coefficients in plate heat exchangers with temperature oscillation IR thermography and CFD. Int. J. Heat Mass Transf. 2010, 53, 3764-3781. [CrossRef]

37. NBE-CT-79. Norma Básica de la Edificación sobre Condiciones Térmicas de los Edificios. REAL DECRETO 2429/1979, de 6 de julio de la Presidencia del Gobierno. Available online: https:/ / www.boe.es/diario_boe/ txt.php?id=BOE-A-1979-24866 (accessed on 15 February 2018).

38. UNE EN ISO 7726: Ergonomics of the Thermal Environment-Instruments for Measuring Physical Quantities. Available online: https://www.din.de/en/wdc-beuth:din21:86800774?sourceLanguage\& destinationLanguage (accessed on 15 February 2018).

39. ISO 13790: 2008 Energy Performance of Buildings-Calculation of Energy Use for Space Heating and Cooling. Available online: https:/ / www.iso.org/obp/ui/\#iso:std:iso:13790:ed-2:v1:en (accessed on 15 February 2018).

40. Orden FOM/588/2017. de 15 de junio, por la que se Modifican el Documento Básico DB-HE “Ahorro de Energía” y el Documento Básico DB-HS “Salubridad”, del Código Técnico de la Edificación, Aprobado por Real Decreto 314/2006, de 17 de Marzo. Available online: https:/ /www.boe.es/diario_boe/txt.php?id= BOE-A-2017-7163 (accessed on 15 February 2018).

41. Roache, P.J. Quantification of uncertainty in computational fluid dynamics. Annu. Rev. Fluid Mech. 1997, 29, 123-160. [CrossRef]

42. CD-Adapco, User Guide. Star CCM+ 8.06.005, 2013. Available online: https://mdx.plm.automation.siemens. com/star-ccm-plus (accessed on 10 December 2007).

43. Catalina, T.; Virgone, J.; Kuznik, F. Evaluation of thermal comfort using combined CFD and experimentation study in a test room equipped with a cooling ceiling. Build. Environ. 2009, 44, 1740-1750. [CrossRef]

44. Peng, L.; Nielsen, P.V.; Wang, X.; Sadrizadeh, S.; Liu, L.; Li, Y. Possible user-dependent CFD predictions of transitional flow in building ventilation. Build. Environ. 2016, 99, 130-141. [CrossRef]

45. Santa, C.; Astorqui, J.; Porras-Amores, C. Ventilated Façade with double chamber and flow control device. Energy Build. 2017, 149, 471-482. [CrossRef]

46. Sanchez, E.; Rolando, A.; Sant, R.; Ayuso, L. Influence of natural ventilation due to buoyancy and heat transfer in the energy efficiency of a double skin facade building. Energy Sustain. Dev. 2016, 33, 139-148. [CrossRef]

47. Hussain, S.; Oosthuizen, P.H. Validation of numerical modeling of conditions in an atrium space with a hybrid ventilation system. Build. Environ. 2012, 52, 152-161. [CrossRef]

48. Wang, Y.; Chen, Y.; Zhou, J. Dynamic modeling of the ventilated double skin façade in hot summer and cold winter zone in China. Build. Environ. 2016, 106, 365-377. [CrossRef]

49. Holman, J.P. Heat Transfer, 8th ed.; McGraw Hill: New York, NY, USA, 2001; ISBN 978-0-07-352936-3.

50. Technic Comitee AEN/CTN 81. ISO 7730:2005 Ergonomics of the Thermal Environment-Analytical Determination and Interpretation of Thermal Comfort Using Calculation of the PMV and PPD Indices and Local Thermal Comfort Criteria; ISO: Geneva, Switzerland, 2005.

51. D'Ambrosio Alfano, F.R.; Palella, B.I.; Riccio, G. Notes on the Calculation of the PMV index by means of Apps. Energy Procedia 2016, 101, 249-256. [CrossRef]

52. D'Ambrosio Alfano, F.R.; Palella, B.I.; Riccio, G.; Totfum, J. Fifty years of Fangers equation: Is there anything to discover yet? Int. J. Ind. Ergon. 2018, in press. [CrossRef]

53. D'Ambrosio Alfano, F.R.; Olesen, B.W.; Palella, B.I. Povl Ole Fanger's impact ten years later. Review article. Energy Build. 2017, 152, 243-249. [CrossRef]

54. D'Ambrosio Alfano, F.R.; Dell'Isola, M.; Palella, B.I.; Riccio, G.; Russi, A. On the measurement of the mean radiant temperature and its influence on the indoor thermal environment assessment. Build. Environ. 2013, 63, 79-88. [CrossRef]

55. Gan, G. Evaluation of room air distribution systems using computational fluid dynamics. Energy Build. 1995, 23, 83-93. [CrossRef] 
56. Gao, S.; Li, Y.; Wang, Y.A.; Meng, X.Z.; Zhang, L.Y.; Yang, C.; Jin, L.W. A human thermal balance-based evaluation of thermal comfort subject to radiant cooling system and sedentary status. Appl. Therm. Eng. 2017, 122, 461-472. [CrossRef]

57. Gao, S.; Wang, Y.A.; Zhang, S.M.; Zhao, M.; Meng, X.Z.; Zhang, L.Y.; Yang, C.; Jin, L.W. Numerical Investigation on the Relationship between Human Thermal Comfort and Thermal Balance under Radiant Cooling System. Energy Procedia 2017, 105, 2879-2884. [CrossRef]

58. Huan, C.; Wang, F.H.; Lin, Z.; Wu, X.Z.; Ma, Z.J.; Wang, Z.H.; Zhang, L.H. An experimental investigation into stratum ventilation for the cooling of an office with asymmetrically distributed heat gains. Build. Environ. 2016, 110, 76-78. [CrossRef]

(C) 2018 by the authors. Licensee MDPI, Basel, Switzerland. This article is an open access article distributed under the terms and conditions of the Creative Commons Attribution (CC BY) license (http:/ / creativecommons.org/licenses/by/4.0/). 